REVISTA de

PEDAGOGIE

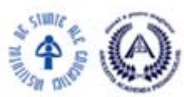

JOURNAL of

PEDAGOGY

http://revped.ise.ro

Print ISSN 0034-8678; Online ISSN: 2559 - 639X

\title{
CAUSES OF SCHOOL VIOLENCE AND POSSIBLE REMEDIAL MODELS
}

CAUZE ALE VIOLENȚEI ȘCOLARE ȘI POSIBILE MODELE REMEDIALE

\section{Otilia APOSTU}

Journal of Pedagogy, 2018 (1), 111-134

https://doi.org/10.26755/RevPed/2018.1/111

The online version of this article can be found at: http://revped.ise.ro/category/2018-en/

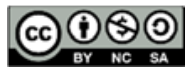

This work is licensed under the Creative Commons Attribution-NonCommercial-ShareAlike 4.0 International License. 94042, USA.

Published by:

\section{INSTITUTUL DE ȘTIINȚE ALE EDUCAȚIEI}

http://www.ise.ro/

Further information about Revista de Pedagogie - Journal of Pedagogy can be found at:

Editorial Policy: http://revped.ise.ro/editorial-policy/

Author Guidelines: http://revped.ise.ro/the-writer-guide-2/ 


\title{
STUDII EMPIRICE
}

\section{CAUZE ALE VIOLEN EI ŞCOLARE ŞI POSIBILE MODELE REMEDIALE}

\author{
Institutul de Ştiin e ale Educa iei \\ Bucureşti / România \\ otilia.apostu@ise.ro
}

\section{Otilia Apostu*}

\section{Rezumat}

Violen a şcolară este o manifestare la fel de veche ca istoria şcolii. Formele de realizare, intensitatea şi frecven a manifestărilor violente, implicarea diferi ilor actori ai şcolii în ini ierea acestora, dar şi percep ia şi toleran a opiniei publice fa ă de formele de violen ă şi actorii ei sunt cele care variază de-a lungul timpului, conferindu-le specificitate şi în elegere diferită. Violen a manifestată în spa iul şcolar are forme variate de manifestare, iar pentru combaterea şi prevenirea ei, esen iale sunt conştientizarea şi acceptarea fenomenului în contextul larg al cauzelor care au determinat-o. Prezentul studiu este focalizat pe cauzele violen ei şcolare, în directă rela ie cu factorii determinan i ai acesteia (individuali, socio-familiali şi şcolari), şi sunt analizate la trei niveluri diferite de manifestare: violen a între elevi, violen a elevilor asupra profesorilor, violen a profesorilor asupra elevilor.

Prezentul studiu se bazează pe date de anchetă care investighează fenomenul violen ei şcolare la nivel na ional, din perspective multiple. Analiza realizată utilizează date cantitative ob inute în cadrul unor anchete prin chestionar adresate elevilor, directorilor, profesorilor, consilierilor şcolari, precum şi date calitative ob inute în cadrul unor anchete prin interviuri focalizate de grup realizate cu elevi, cadre didactice, părin i. Analizele întreprinse permit punerea în rela ie a opiniilor diferi ilor actori ai

* Cercetător ştiin ific II dr., Institutul de Ştiin e ale Educa iei, Bucureşti, România. 
şcolii asupra cauzelor violen ei şcolare, care, uneori, sunt antagoniste. Provocarea prezentului studiu nu este determinarea veridicită ii sau importan ei cauzelor violen ei şcolare identificate de actorii şcolii, ci pornind de la aceste cauze vor fi identificate măsuri, strategii, politici a căror implementare ar putea conduce la o vedere unitară a actorilor şcolii asupra problematicii violen ei şcolare şi la reducerea şi combaterea manifestărilor violente la nivelul şcolii.

Cuvinte-cheie: politici educa ionale, preven ie şi combatere a violen ei, violen ă şcolară.

\section{Abstract}

School violence is a manifestation as old as the history of the school. The forms and the frequency of violent manifestation, the involvement of the school actors for the initiation of violent demonstrations, as well as the perception and tolerance of public opinion about the forms of violence and its actors are those that vary throughout time, giving them specificity and differentiated understanding. School violence includes various forms of manifestation, and to combat and prevent it, it is essential to raise awareness of the phenomenon of violence and its acceptance in the wider context of the determining causes. This study focuses on the causes of school violence directly correlated with the determinants (individual, sociofamilial, school), analysed at three different levels of manifestation: violence between students, violence students - teachers, violence teachers - students.

The study uses survey data that explores the phenomenon of school violence at the national level, from multiple perspectives. The analysis uses quantitative data obtained through questionnaire surveys addressed to pupils, principals, teachers, school counsellors, as well as qualitative data obtained by surveys by focus group interview, carried out with students, teachers and parents. The analyses relate the opinions, sometimes antagonistic, of the different school actors on the causes of school violence. The purpose of the study is not to determine the truth or importance of the causes of school violence identified by the school actors, but from these causes will be identified measures, strategies, policies that implementation will lead to a unitary view of school actors on the problem of school violence and the reduction and control of violent manifestations at school.

Keywords: educational policies, prevention and fight against violence, school violence. 


\section{Contextualizare}

Violen a manifestată la nivelul şcolii a fost întâlnită de-a lungul istoriei educa iei, diferen a fiind dată de formele de manifestare, intensitate, frecven ă, dar şi de percep ia şi toleran a opiniei publice fa ă de formele de violen ă şi actorii ei. Violen a în spa iul şcolar poate lua forme variate, dar dincolo de inventarierea şi analiza acestora, importante sunt conştientizarea şi acceptarea fenomenului, astfel încât să fie explorate cauzele concrete, în vederea combaterii celor existente şi prevenirii apari iei altora. Este motivul pentru care, în analiza care urmează, vom orienta aten ia asupra cauzelor care stau la baza comportamentelor violente la nivelul şcolii. Corelat, vom face referiri la factorii de risc pentru apari ia violen ei şcolare.

Există numeroase studii cu privire la factorii care stau la baza violen ei şi agresivită ii (Pain, 1997; Debarbieux, 1999, 2006; Dubet, 2002; Bègue, 2004), clasificările fiind variate şi influen ate de paradigmele la care au aderat diferi ii cercetători în domeniul violen ei. În analiza noastră, vom valorifica acele abordări/clasificări ale factorilor de risc pentru apari ia violen ei, care iau în considerare actorii şcolii: individul, şcoala, familia/comunitatea, determinând cele trei categorii de factori cu care vom opera: factori individuali, factori socio-familiali şi factori şcolari.

La nivelul factorilor individuali, comportamentul violent poate fi influen at de caracteristici biologice, psihologice sau sociale, unele dintre acestea neconstituind obiectul abordărilor prin cercetarea noastră (de exemplu, caracteristicile biologie). Din totalitatea caracteristicilor determinante ale violen ei la nivel individual, am re inut, pentru analiza de fa $\breve{a}$, aspecte ce in de: specificitatea individului, aflându-se la intersec ia factorilor biologici şi psihologici; impulsivitatea, lipsa controlului, afirmarea Eu-lui, dorin a de putere şi prestigiu (caracteristicile psihologice fiind avute aici în vedere); elemente ce in de experien a personală şi percep ia asupra acesteia (caracteristicile psihologice şi sociale fiind definitorii).

Din perspectiva factorilor socio-familiali, comportamentul violent poate fi determinat de: climatul socio-afectiv în care trăieşte copilul, modelul familial existent/valorizat (tipul, dimensiunea familiei), condi iile materiale ale familiei, 
modelele de rela ionare promovate, sistemul de valori la care se raportează familia.

Factorii şcolari care pot influen a comportamentul violent in de climatul existent la nivelul unită ii şcolare (fie de concuren ă excesivă, fie prea permisiv), dar şi de disonan a pe care o determină la nivelul actorilor şcolari impunerea for ată a unor norme.

Influen a diferen iată a acestor factori la nivel individual este un aspect asupra căruia nu vom insista. Cercetarea s-a concentrat pe intensitatea cu care aceşti factori sunt identifica i şi conştientiza i în percep ia actorilor şcolii: elevi, profesori, consilieri şcolari, directori. Pentru că rela iile şi implica iile faptelor de violen ă asupra actorilor şcolii sunt variate, nu putem opera decât cu o analiză distinctivă, clară pe trei direc ii de ac iune violentă: elevi - elevi, elevi - profesori, profesori - elevi.

\subsection{Metodologia de cercetare}

Studiul realizat cu privire la cauzele violen ei şcolare au fost colectate în cadrul proiectului Pilotarea unei noi metodologii de analiză a fenomenului de violen ă în spa iul şcolar, dezvoltat de Institutul de Ştiin e ale Educa iei cu sprijinul Reprezentan ei UNICEF România. Scopul proiectului a vizat elaborarea unei metodologii specifice de cercetare a problematicii violen ei şcolare. Pentru aceasta, în sintagma violen $\breve{a}$ şcolară a fost inclusă orice ac iune şi/sau manifestare cu efecte de ordin fizic sau psihic asupra persoanelor din spa iul şcolar sau asupra resurselor materiale ale şcolii. În investigarea fenomenului de violen ă şcolară, au fost avute în vedere toate formele de manifestare a violen ei şcolare, incluse în Nomenclatorul actelor de violen $\breve{a}$ (ISE, 2011).

Proiectul în cadrul căruia a fost realizată prezenta analiză a avut ca obiective dezvoltarea unei metodologii de analiză a violen ei şcolare adaptate noilor priorită i în domeniu, pilotarea şi analiza unor metode şi instrumente relevante pentru investigarea fenomenului de violen ă şcolară, formularea unor ac iuni ameliorative în domeniul violen ei şcolare. 
Prezentul studiu este o componentă în cadrul cercetării ample realizate şi a contribuit, prin abordarea particularizată la nivelul cauzelor violen ei şcolare, la realizarea obiectivelor generale ale studiului mai sus men ionat. Analiza de fa ă a urmărit o serie de obiective specifice, adaptate, particularizate şi care se focalizează pe:

- Identificarea principalelor cauze care determină manifestările violente între diferi ii actori ai şcolii;

- Analiza dinamicii responsabilizării invocate de diferi ii actori implica i în fenomenul violen ei şcolare;

- Elaborarea unor recomandări de politică educa ională care să ac ioneze în vederea prevenirii şi combaterii violen ei şcolare.

În vederea realizării acestor obiective, a fost necesară culegerea unor date complexe, pentru care s-a făcut apel la analiză documentară şi utilizarea unor instrumente cantitative de cercetare (chestionare adresate elevilor, directorilor, cadrelor didactice, consilierilor şcolari). Cele patru chestionare distincte au fost elaborate corelat, astfel încât aspectele supuse investiga iei să fie similare, dar adresate adaptat specificului fiecărui grup investigat. Instrumentele au fost aplicate prin autoadministrare şi au vizat aspecte precum: context socio-economic al şcolii şi comunită ii; caracteristici ale şcolii (resurse umane, dimensiune, situarea şcolii în comunitate, elemente de absenteism şi abandon şcolar); tipuri de violen ă şcolară şi forme de manifestare la nivelul şcolii; intensitatea actelor de violen ă şi cauzele care le-au general; masuri de prevenire şi combatere implementate la nivelul şcolii.

Popula ia investigată, fără a avea preten ia de reprezentativitate la nivel na ional, s-a constituit din peste 2100 de subiec i proveni i din 90 de unită i de învă ământ din 14 jude e. Pe categorii de responden i, la anchetă au participat: 69 de directori, 354 de profesori, 1656 de elevi din clase terminale (70\% elevi de gimnaziu, 30\% elevi de liceu), 58 de consilieri şcolari.

Analiza datelor de anchetă a facilitat ob inerea unor informa ii relevante cu privire la: estimarea dimensiunii fenomenului de violen ă şcolară, forme ale violen ei şcolare, cauze ale violen ei şcolare, strategii şi ac iuni de prevenire a violen ei şcolare. Ne vom concentra aten ia, în prezenta analiză, doar asupra cauzelor care favorizează apari ia actelor de violen ă în spa iul şcolar, identificate de diferi i actori ai şcolii (elevi, manageri şcolari, profesori, consilieri şcolari). 


\section{Cauze ale violen ei între elevi}

Cauzele violen ei care apare între elevi sunt percepute diferit de elevi şi profesori. Elevii identifică mai curând în spa iul şcolar factorii care influen ează violen a pe care o manifestă fa ă de al i colegi, în timp ce cadrele didactice plasează această influen ă la nivelul familiei şi al grupului de prieteni. Această pasare ,în oglindă” a responsabilită ii pentru apari ia faptelor de violen ă ridică semne de întrebare asupra cunoaşterii pe care categoriile de actori o au asupra cauzelor reale care favorizează apari ia violen ei în spa iul şcolar, cât şi asupra recunoaşterii determinan ilor personali sau institu ionali (familie, sistem de educa ie) asupra violen ei. Analiza datelor de cercetare va oferi o perspectivă de ansamblu asupra cauzelor violen ei, fiind, totodată, un punct de plecare pentru elaborarea unor strategii de prevenire şi combatere a violen ei şcolare.

\subsection{Factori individuali care determină violen a între elevi}

Ancheta realizată în rândul elevilor a inclus o serie de aspecte variate de ordin individual, în general orientate spre domeniile psihologic şi social, având în vedere că dimensiunea biologică/genetică implică investiga ii aprofundate care nu pot fi explorate în cadrul unei anchete prin chestionar autoaplicat.

Din perspectiva factorilor individuali, elevii atribuie cel mai frecvent răspunderea pentru determinarea violen ei către factorii psihologici (trăsături de dezvoltare) ce in de reac ia adolescen ilor la impunerea for ată a autorită ii $(56,1 \%)$ şi capacitatea scăzută de gestiune a emo iilor $(55,1 \%)$. Ambii factori îşi pot reduce influen a asupra comportamentului elevilor prin promovarea unei atitudini deschise a şcolii fa ă de normele impuse, prin informarea elevilor cu privire la demersurile întreprinse, măsurile adoptate şi, acolo unde este posibil, negocierea luării deciziilor împreună cu elevii. Capacitatea scăzută de gestionare a emo iilor negative poate fi depăşită prin activită i de consiliere, dar şi prin activită i educa ionale de valorificare a inteligen ei emo ionale a elevilor, pe care fiecare cadru didactic le poate realiza în activită ile şcolare şi extraşcolare. Influen a celor doi factori personali des men iona i de elevi ca fiind determinan i pentru violen a dintre elevi este mai frecvent men ionată de către elevii din mediul rural, unde consilierii şcolari sunt, de altfel, mai pu in prezen i în şcoli. 
De remarcat este ponderea zero a răspunsurilor care vizează comunicarea şi rela ionarea la nivelul grupului ca fiind cauză a comportamentelor violente, fapt ce poate fi interpretat din două perspective: fie că elevii nu au probleme de comunicare şi rela ionare, fie că ei nu le conştientizează ca fiind determinante pentru apari ia faptelor de violen $\breve{\text {. }}$

Abilită ile de comunicare şi rela ionare în grup sunt, însă, văzute de profesori (54\%) şi de directori (58\%) ca principali determinan i individuali ai violen ei între elevi. Diferen a de perspectivă dintre cele două grupuri poate fi determinată - pe de o parte - de o cunoaş̧ere incompletă a cadrelor didactice asupra sistemelor de comunicare şi rela ionare a elevilor, sisteme pe care aceştia le dezvoltă, le adaptează sub influen a factorilor sociali asupra cărora adultul este posibil să nu aibă un punct de vedere obiectiv, fundamentat. Pe de altă parte, la nivelul grupurilor de elevi pot exista tensiuni, rela ionare deficitară determinate de climatul şcolar, de lipsa de coeziune a grupului, de cunoaşterea limitată şi deficitară dintre colegi.

Graficul nr. 1. Factori individuali determinan i ai violen ei între elevi ${ }^{l}$

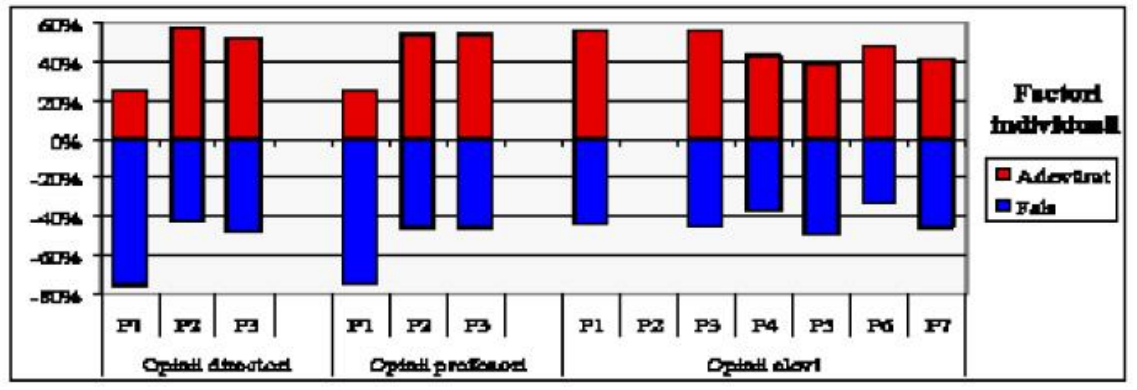

Factori individuali (P):

P1: reac ia elevilor la impunerea for ată a autorită ii de către al i elevi

P2: insuficienta dezvoltare a abilită ilor de comunicare şi de rela ionare în grup

P3: dificultă i personale la nivel de gestiune a emo iilor (negative)

P4: sunt violen i de felul lor

P5: sunt invidioşi

P6: se simt nedreptă i i

P7: nu îşi pot controla furia, supărarea 
Un numitor comun al celor două grupuri - de elevi, respectiv de cadre didactice (incluzând şi directorii) - este dat de dificultă ile elevilor de a-şi gestiona emo iile (negative). Peste jumătate dintre profesori identifică acest factor ca fiind determinant pentru apari ia faptelor de violen ă. La nivelul grupului de directori se constată că cei proveni i din mediul urban şi din licee invocă mai des incapacitatea elevilor de a-şi gestiona emo iile în rela iile cu colegii.

\subsection{Factori socio-familiali determinan i ai violen ei între elevi}

Factorii socio-familiali incluşi în analiză fac referire la preluarea unor modele de comportament din familie, grupul de prieteni, mass-media, spa iul virtual. Şi la acest nivel există diferen e între declara iile elevilor şi cele ale cadrelor didactice (inclusiv directori). Trebuie men ionat faptul că, în general, factorii socio-familiali primesc mai mult credit în determinarea faptelor de violen ă şi în opinia elevilor, şi în opinia cadrelor didactice.

Conform perspectivei elevilor, mass-media este principalul factor de influen ă asupra comportamentelor negative manifestate de elevi $(69,6 \%)$. Având în vedere concluziile unor studii din domeniul educa iei care eviden iază că o pondere semnificativă din timpul elevilor este destinat mass-mediei (Jigău, 2008), datele de cercetare confirmă faptul că sunt necesare campanii de informare cu privire la consumul media recomandat tinerilor, propunerea unor alternative pentru tineri la consumul de media, educarea tinerilor consumatori de mass-media în vederea unui consum limitat şi a alegerii emisiunilor care să contribuie la dezvoltarea personală, socială, profesională. $\mathrm{Al}$ i determinan i pentru comportamentele violente ale elevilor sunt, în ponderi comparabile, grupul de prieteni şi spa iul virtual (67,6\%, respectiv 67\%). Sunt factori asupra cărora adul ii intervin mai pu in din cauza accesului limitat pe care fiecare dintre aceşti factori îl oferă ,actorilor externi”.

Influen a familiei este plasată de elevi pe ultimul loc în această categorie de factori, la o diferen ă sesizabilă fa ă de grupul cadrelor didactice.

Cadrele didactice şi directorii consideră că familia este principala responsabilă pentru comportamentul violent al elevilor, prin preluarea modelului sau prin traume pe care copiii le-au trăit în cadrul familiei, de 
timpuriu. Această perspectivă explicativă este mai mult sus inută de directorii şi profesorii şcolilor gimnaziale decât de cei din licee, respectiv este mai mult sus inută de directori şi profesori din mediul rural decât de cei din urban. Această situa ie poate fi determinată de dimensiunea şcolii (în şcolile mai mici cresc şansele ca profesorii să-şi cunoască mai bine elevii şi familiile lor), dar şi a comunită ii de apartenen ă. $\mathrm{O}$ bună cunoaştere între şcoală elev - familie prin activită i şcolare şi extraşcolare ar putea reduce diferen ele de cunoaştere şi de percep ie asupra factorilor socio-familiali şi influen ei lor efective asupra comportamentului violent.

Influen a modelelor de rela ionare din familie este, în opinia directorilor şi profesorilor, principalul determinant al violen ei manifestate de elevi.

Graficul nr. 2. Factori socio-familiali determinan i ai violen ei între elevi

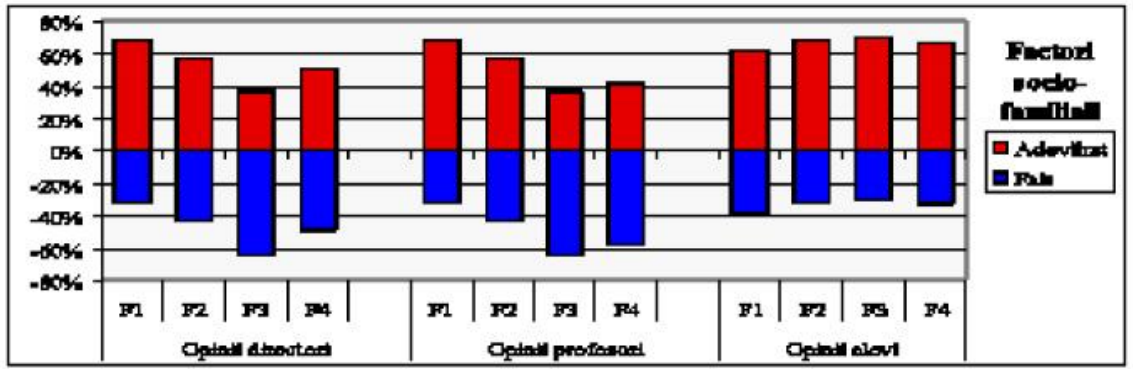

Factori de mediu socio-familial (F):

F1: preluarea unor modele de rela ionare din familie

F2: preluarea unor modele de rela ionare din diferite grupuri

F3: preluarea unor modele de rela ionare din mass-media

F4: influen a negativă a mediului virtual

2.3. Factori şcolari determinan i ai violen ei între elevi

Factorii de mediu şcolar includ elemente ce vizează condi iile, ambian a în care se desfăşoară activită ile şcolare şi extraşcolare, dar şi rela iile dintre elevi şi aspecte de ethos educa ional. Fie că este vorba despre climatul concuren ial, fie că este vorba despre un climat permisiv, între elevi şi cadre didactice există în elegeri diferite cu privire la influen a factorilor şcolari asupra violen ei. 
În percep ia elevilor, factorii şcolari sunt principalii determinan i pentru comportamentul violent al elevilor. Procente semnificative înregistrează şi cei care consideră că un climat de concuren ă/competi ie determină manifestări violente $(79,6 \%)$ şi cei care cred că astfel de comportamente sunt favorizate de un climat prea permisiv $(77,8 \%)$.

Cadrele didactice şi directorii acordă, în general, pu in credit acestor factori, chiar dacă la nivelul celor două grupuri de actori apar unele diferen e. Per ansamblu, actorii şcolii responsabili pentru organizarea şi derularea activită ii didactice, dar şi pentru asigurarea unui mediu de învă are plăcut, securizant consideră (în propor ii comparabile de aproximativ 15\%) că impunerea unor norme de către şcoală, neasumate la nivel personal, de elev, poate determina comportamente violente.

Mai mul i directori decât profesori consideră că un mediu concuren ial poate determina comportamente violente la nivelul elevilor, dacă nu este gestionat eficient şi constructiv. Această diferen ă poate fi determinată de cunoaşterea variată pe care profesorii şi directorii o au asupra elevilor (directorii interac ionează mai pu in la clasă cu elevii şi atunci cunoaşterea lor asupra comportamentului elevilor influen at de climatul concuren ial, este mai pu in cunoscută). O altă ipoteză explicativă ce ar trebui testată vizează corela ia

Graficul nr. 3. Factori şcolari determinan i ai violen ei între elevi

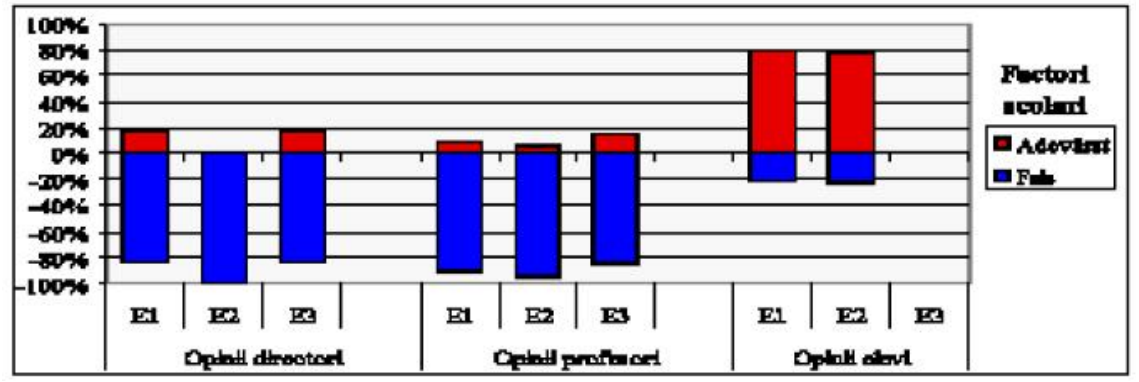

Factori de mediu şcolar (E):

E1: climatul de concuren ă existent în şcoală/clasă

E2: climatul prea permisiv al şcolii

E3: impunerea unor norme comportamentale de către şcoală, neasumate la nivel personal de elevi 
cu atitudinea profesorilor fa ă de concuren ă: un profesor care încurajează, stimulează, valorizează concuren a între elevi va recunoaşte mai pu in influen ele pe care un astfel de climat şcolar le are asupra comportamentului elevilor.

Climatul prea permisiv al şcolii este factorul care, în opinia cadrelor didactice şi a directorilor, nu conduce la acte de violen ă între elevi.

\section{Cauze ale comportamentelor neadecvate ale elevilor fa ă de profesori}

În opinia directorilor şi profesorilor, cauzele violen ei elevilor fa ă de profesori sunt atribuite mai curând factorilor individuali şi socio-familiali. Elevii identifică la nivelul tuturor factorilor (individuali, socio-familiali, şcolari) elemente ce pot determina manifestări agresive verbale şi/sau fizice ale lor fa ă de profesori. De remarcat sunt ponderile mult mai echilibrate ale răspunsurilor elevilor cu privire la determinan ii violen ei elev - profesor, fa ă de răspunsurile cadrelor didactice şi directorilor, care se concentrează asupra factorilor individuali şi asupra unor factori socio-familiali.

3.1. Factori individuali determinan i ai violen ei elevilor fa ă de profesori

Cele mai multe dintre cadrele didactice participante la anchetă au men ionat ca determinant al violen ei elevilor fa ă de profesori lipsa de interes şi motiva ie a elevilor fa ă de învă are (69,6\% dintre directori, respectiv 64,7\% dintre profesori). Procentele semnificative înregistrate eviden iază o detaşare a personalului şcolii fa ă de problematica violen ei manifestată de elevi fa ă de cadrele didactice. Plasând cauza la nivel individual, şcoala va fi pu in activă din perspectiva reducerii influen ei pe care o are din interiorul organiza iei, asupra agresivită ii elevilor fa ă de profesori. Atâta timp cât şcoala nu conştientizează sau nu acceptă printre cauzele violen ei propriile ac iuni directe sau indirecte ale personalului sau a elementelor ce in de organizare, func ionare, nu va putea ini ia demersuri corective ale comportamentelor agresive ale elevilor fa ă de profesori. 
Chiar dacă, în general, influen a interesului şi motiva iei scăzute pentru învă are asupra violen ei elevilor fa ă de profesori nu înregistrează varia ii semnificative între mediile de reziden ă, un aspect se remarcă: mai curând directorii din mediul rural, respectiv cadrele didactice din mediul urban sus in rela ia de determinare puternică dintre lipsa interesului şi motiva iei pentru învă are şi agresivitatea elevilor fa ă de profesori.

Elevii plasează şi ei factorii individuali, cu referire directă la lipsa de interes şi motiva ie pentru învă are, printre principalele cauze ale agresivită ii elevilor fa ă de profesori, însă ponderea acestei op iuni este devansată de cea care privilegiază preluarea unor comportamente din diferite grupuri (factor social). Mai mult de un sfert dintre elevi consideră că una dintre cauzele principale ale violen ei elevilor fa ă de profesori se datorează lipsei de interes şi motiva ie pentru învă are, nefiind înregistrate diferen e semnificative în func ie de mediul de reziden ă, nivelul de educa ie în care este cuprins elevul, sex. Elevii cu medii şcolare slabe şi elevii proveni i din familii cu nivel redus de educa ie realizează o asociere slabă între lipsa de interes pentru învă are şi violen a fa ă de profesori. Această legătură este mai curând realizată de elevii ai căror părin i sunt absolven i de cel pu in învă ământ postliceal.

Graficul nr. 4. Factori individuali determinan i ai violen ei elevilorfa $\breve{a}$ de profesori

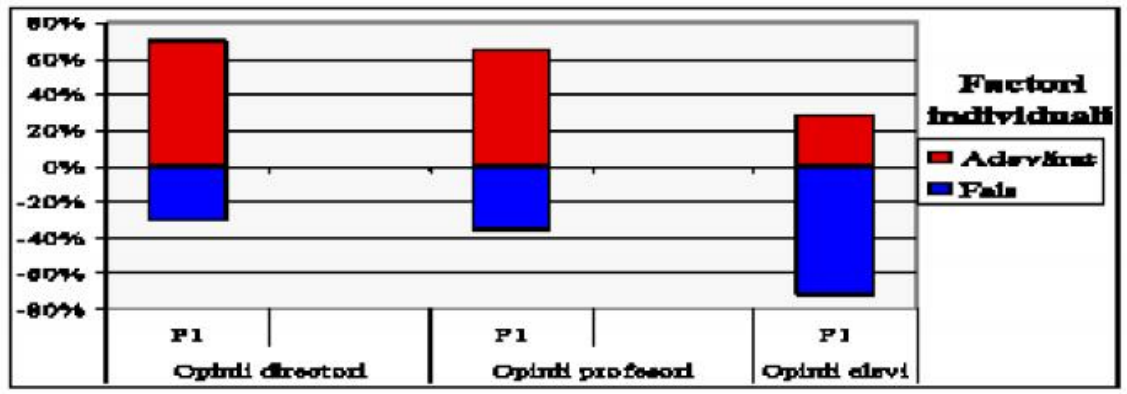

Factori individuali $(\mathrm{P})$ :

P1: lipsa de interes şi motiva ie a elevilor pentru învă are 
Consilierii şcolari au o viziune mai elaborată asupra cauzelor comportamentelor agresive ale elevilor manifestate la nivelul şcolii. Discu iile cu elevii şi profesorii conduc la o cunoaştere mai aprofundată a cauzelor care au condus la comportamente inadecvate şi care pot constitui resurse semnificative pentru propunerea unor demersuri de prevenire şi combatere a acestor compor-tamente.

Din perspectiva consilierilor şcolari, principalii factori determinan i ai violen ei elevilor fa ă de cadrele didactice sunt rezultatul unor trăsături personale ce in de latura emo ională $(69 \%)$, de toleran ă $(67,2 \%)$, dar şi de capacitatea de rela ionare la nivel de grup $(63,8 \%)$. La nivel gimnazial ierarhia se păstrează, însă la nivel liceal complexele acumulate constituie principalul determinant individual pentru manifestarea agresivită ii.

Cel mai pu in influent factor individual al agresivită ii elevilor fa ă de profesori ine de diferite tipuri de dizabilitate $(12,1 \%)$, fapt ce constituie un argument în favoarea sus inerii integrării elevilor cu dizabilită i uşoare în învă ământul de masă.

\subsection{Factori socio-familiali determinan i ai violen ei elevilor fa ă de profesori}

Chiar dacă în cazul cadrelor didactice oricare dintre factorii socio-familiali sunt devansa i de factorii individuali în rela ia de determinare a violen ei elevilor fa ă de profesori, există factori socio-familiali des invoca i în această rela ie. Astfel, şi în cazul directorilor, şi în cazul cadrelor didactice, preluarea modelelor de rela ionare din familie, respectiv din diferite grupuri constituie principalele două cauze ale comportamentelor agresive ale elevilor fa ă de profesori. Există un singur factor şcolar care devansează oricare dintre ponderile factorilor socio-familiali determinate pentru influen a asupra comportamentului agresiv al elevilor fa ă de profesori.

Principalul factor de ordin socio-familial men ionat ca fiind determinant al agresivită ii elevilor fa ă de profesori este preluarea unor modele de rela ionare din familie, la care aderă 58\% dintre directorii chestiona i şi 56,5\% dintre profesori. Chiar dacă aparent există unele diferen e pe subcategorii 
ale personalului din învă ământ, la nivel general nu există diferen e majore între opiniile cadrelor didactice în func ie de mediul de reziden ă.

Tipul şcolii aduce oarecare diferen e la nivelul opiniilor exprimate de directori - cei din şcolile gimnaziale acordând mai mult credit influen ei familiei asupra comportamentului elevilor decât directorii de licee. Acest fapt se poate datora, în principal, vârstei elevilor din şcolile pe care le conduc şi care o dată cu înaintarea în vârstă şi trecerea de la un nivel de educa ie la altul sunt tot mai mult ataşa i şi influen a i de grupul de prieteni. Debutul şcolarizării la liceu se suprapune cu trecerea copilului la adolescen ă, manifestată prin dorin a de intrare şi chiar intrarea efectivă în via a socială şi culturală. Prin natura umană şi uneori prin plecarea copilului de acasă pentru continuarea studiilor liceale în altă localitate, copilul se desprinde, treptat, de influen a principală a familiei şi intră în ,familii sociale” de la care preia modele comportamentale prin imita ie şi pentru a fi acceptat de grupul de prieteni. Având în vedere acestea, este firesc ca directorii şi profesorii de liceu să atribuie influen ei grupului de prieteni o mai mare importan ă decât influen ei familiei, în determinarea comporta-mentelor de orice tip, inclusiv celor agresive.

Trebuie men ionat faptul că influen a mass-media şi a mediului virtual sunt, de asemenea determinante pentru comportamentul agresiv al elevilor fa ă de profesori pentru aproximativ o treime dintre cadrele didactice.

În cazul elevilor, preluarea modelelor de rela ionare/comportament preluate din diferite grupuri este argumentul cel mai des invocat în cadrul tuturor factorilor determinan i ai violen ei şcolare (32\%). Această perspectivă este mai curând împărtăşită de elevii din mediul urban decât de cei din rural, respectiv de elevii din liceu fa ă de cei din învă ământul gimnazial. Acest fapt se datorează contextelor mai numeroase şi mai variate în care elevii din oraşe şi cei din învă ământul postgimnazial au ocazia să rela ioneze cu convârstnicii.

Ceilal i factori socio-familiali înregistrează ponderi semnificative în opiniile elevilor, pentru fiecare dintre ei optând aproximativ un sfert dintre elevii chestiona i. Pentru acestea, în general, nu există varia ii semnificative din perspectiva mediului de provenien ă al elevului, nivelului de educa ie urmat sau al genului. Singura men iune care necesită aten ie este ponderea mai 
crescută a elevilor de nivel liceal care atribuie modelelor preluate din familie o influen ă majoră asupra comportamentelor agresive ale elevilor fa ă de profesori. Probabil această opinie care caracterizează o treime a elevilor din liceu este facilitată de capacită ile crescute ale elevilor de nivel liceal de analiză, realizare a compara iilor, identificării cauzalită ilor.

Graficul nr. 5. Factori socio-familiali determinan i ai violen ei elevilor fa $\breve{a}$ de profesori

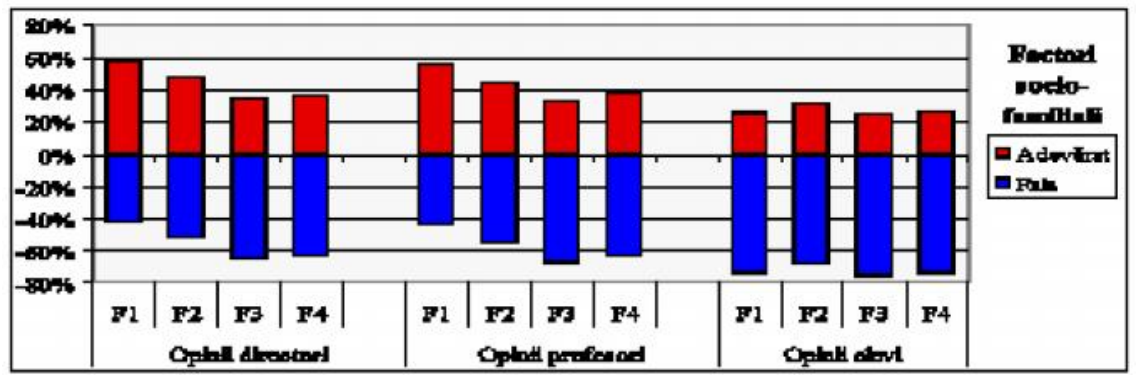

Factori socio-familiali (F):

F1: preluarea unor modele de rela ionare din familie

F2: preluarea unor modele de rela ionare din diferite grupuri

F3: preluarea unor modele de rela ionare din mass-media

F4: influen a negativă a mediului virtual

Consilierii şcolari confirmă, prin experien a de consiliere, influen a rela iilor conflictuale din familie asupra comportamentelor agresive ale elevilor. Peste $72 \%$ dintre consilierii şcolari sus in această paradigmă care este urmată de cele care dau credit argumentelor referitoare la familiile dezorganizate şi la nivelul redus de instruire a părin ilor. Aceste dominante de la nivelul factorilor familiali se regăsesc atât la nivel gimnazial, cât şi la nivel liceal, însă la acesta din urmă se eviden iază încă un factor - lipsa/insuficienta preocupare a părin ilor pentru copii $(73,7 \%)$. La acest nivel controlul parental se diminuează fie datorită vârstei (trăsăturilor specifice vârstei) şi tendin ei de manifestare a independen ei, fie a plecării copilului de la domiciliul părin ilor pentru continuarea studiilor, fie datorită scăderii interesului sau capacită ii părin ilor de a-şi impune autoritatea parentală.

Cel mai pu in influent factor de ordin familial face referire la familiile numeroase (17,2\%), probabil datorită dezvoltării unor capacită i de cooperare, 
comunicare în grup lărgit şi care pot fi transferate la nivelul diferitelor grupuri în care este inclus elevul, sau datorită unor ierarhii care (cel pu in în familiile tradi ionaliste) se dezvoltă şi sunt respectate dincolo de limitele grupului familial, la nivelul grupurilor şcolare, sociale, profesionale.

Din perspectivă socială, consilierii şcolari asociază influen a grupurilor de apartenen ă (81\%), de prieteni care oferă contexte de învă are şi socializare elevilor, în timpul petrecut în afara şcolii. Această influen ă este mult mai evidentă la elevii de nivel liceal, perspectivă corelată cu scăderea influen ei familiei asupra comportamentului elevilor. Toate celelalte perspective propuse sunt $\mathrm{cu}$ mult mai pu in influente asupra comportamentelor agresive ale elevilor, decât influen a grupurilor de prieteni.

\subsection{Factori şcolari determinan i ai violen ei elevilor fa ă de profesori}

În perspectiva cadrelor didactice, factorii şcolari au cea mai mică influen ă în determinarea comportamentelor agresive în rândul elevilor fa ă de cadrele didactice. Este un fel de ,protejare a şcolii” şi, implicit, a lor înşişi fa ă de problematica violen ei în spa iul şcolar. Atribuindu-i şcolii o influen ă minimală asupra comportamentului neadecvat al elevilor, nu i se vor atribui nici responsabilită i în aria prevenirii şi combaterii violen ei elevilor, or acest aspect ar trebui să constituie o preocupare constantă a şcolii tocmai pentru a face dovada, alături de alte demersuri întreprinse, de preocupare pentru asigurarea unui învă ământ de calitate elevilor.

Şi directorii şi profesorii asociază comportamentele neadecvate ale elevilor fa ă de profesori unor deficien e de comunicare în rela ia elev - profesor, în special dacă provin din şcoli urbane.

Tot profesorii din urban sunt cei care recunosc, în propor ii mai crescute decât colegii lor din rural, că presta ia lor la clasă poate determina comportamente neadecvate ale elevilor. Acest din urmă aspect înregistrează ponderi reduse în opinia cadrelor didactice, dar de remarcat este diferen a semnificativă pe medii de reziden ă.

Opiniile elevilor fa ă de determinan ii şcolari ai comportamentelor agresive 
ale elevilor fa ă de profesori sunt mai bine conturate decât cele ale cadrelor didactice, în sensul mai bunei reprezentări a fiecăruia dintre factorii men iona i. Violen a elevilor fa ă de profesori determinată de nemul umirea fa ă de presta ia profesorilor la clasă este, şi în cazul elevilor, factorul cel mai slab reprezentat $(17,6 \%)$ din toată seria, dar mai bine reprezentat decât în opiniile cadrelor didactice fa ă de acelaşi aspect. Diferen a pe medii se păstrează şi în acest caz, cu o mult mai redusă reprezentare a opiniei men ionate în rândul elevilor din mediul rural.

Din perspectiva factorilor şcolari, elevii acordă credit pentru agresivitatea elevilor fa ă de profesori impunerii for ate a autorită ii de către profesori $(27,1 \%)$ şi evaluărilor considerate neobiective $(26,9 \%)$. Elevii din mediul urban dau ceva mai mult credit acestor factori decât colegii din rural. Diferen ă semnificativă se înregistrează pe niveluri de educa ie, elevii de liceu fiind mult mai convinşi de determinarea violen ei elevilor prin evaluările neobiective ale profesorilor, decât colegii din gimnaziu. Aceste distribuiri ale opiniilor pot fi influen ate de capacită ile crescute ale elevilor de nivel liceal de a-şi autoevalua competen ele obiectiv prin raportare la colegii de clasă şi/sau la presta iile profesorilor.

Graficul nr. 6. Factori şcolari determinan i ai violen ei elevilor fa $\breve{a}$ de profesori

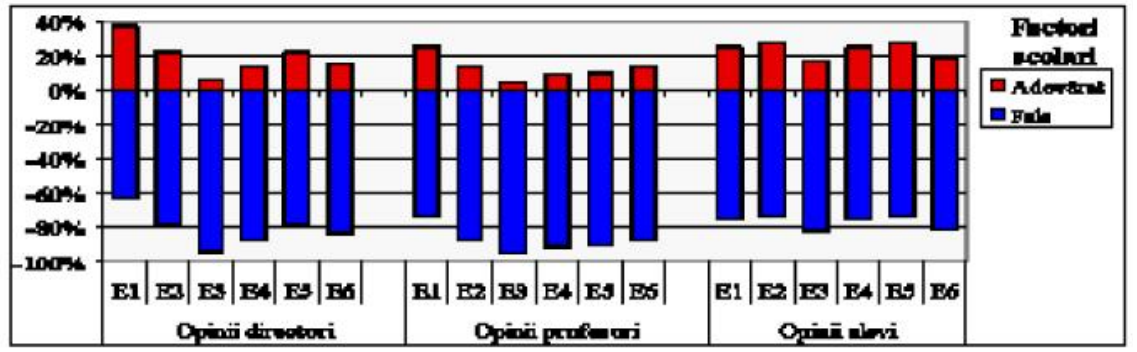

Factori şcolari (E):

E1: deficien e în comunicarea cu profesorii

E2: reac ia elevilor la impunerea for ată a autorită ii profesorilor

E3: nemul umirea elevilor fa ă de presta ia la clasă a profesorilor

E4: sentimentul elevilor că sunt ignora i de către profesori

E5: reac ia elevilor fa ă de evaluări considerate neobiective

E6: reac ia elevilor fa ă de ceea ce înva ă (lipsa de actualitate, de utilitate/aplicabilitate etc.) 
Influen a grupului de prieteni asupra comportamentelor agresive ale elevilor este cel mai frecvent factor şcolar men ionat de consilierii şcolari participan i la anchetă $(67,2 \%)$. Acest aspect vine să întărească influen a grupului asupra comportamentului elevilor ca principal factor socio-familial de determinare a violen ei elevilor fa ă de profesori. Asupra elevilor de gimnaziu, grupul de prieteni de la nivelul şcolii este mai influent decât în cazul elevilor de liceu probabil datorită libertă ii mai mari de alegere a grupurilor de apartenen ă şi a interac iunii cu acestea, pe care o au elevii din liceul. În cazul elevilor de gimnaziu există un control mai strict (cel pu in teoretic) din partea familiei, iar ,libertatea” de alegere a prietenilor se detaşează de controlul familiei.

Al i factori şcolari cu influen ă semnificativă asupra comportamentului agresiv al elevilor fa ă de profesori vizează impunerea unor norme de comportament de către şcoală şi neasumate de elevi, dar şi deficien ele de comunicare între elevi şi cadre didactice $(43,1 \%$ pentru fiecare dintre cei doi factori de influen $\breve{a}$ ).

Conform opiniilor consilierilor şcolari, factorii şcolari au cea mai mică importan ă în economia determinan ilor agresivită ii elevilor. Aceştia înregistrează cel mai mic scor mediu, la polul opus fiind factorii socio-familiali. Aceste informa ii vin să întărească opiniile cadrelor didactice şi ale directorilor care plasează cauzele violen ei şcolare mai curând în afara şcolii, fără a nega şi influen ele pe care înseşi şcoala le are asupra violen ei elevilor.

\section{Cauze ale comportamentelor neadecvate ale profesorilor fa ă de elevi}

Comportamente inadecvate la nivelul şcolii pot fi ini iate şi de profesori şi chiar dacă acestea sunt mai pu in reprezentate decât comportamentele neadecvate ale elevilor, necesită, totuşi, aten ie în investiga ia referitoare la violen a şcolară.

Analiza propusă la nivelul cadrelor didactice din şcoală a vizat cauzele comportamentelor neadecvate ale profesorilor din două perspective: deficien ele de comunicare cu elevii sau părin ii acestora, respectiv factorii de mediu educa ional / condi iile de lucru. În ambele categorii de factori 
determinan i ai agresivită ii profesorilor fa ă de elevi, personalul şcolii (directori, profesori, consilieri şcolari) a avut, în general, opinii convergente.

Din perspectiva deficien elor de comunicare, principalul aspect incriminat de cadre didactice a vizat provocările elevilor. $\mathrm{Cu}$ excep ia directorilor, personalul didactic (profesori şi consilieri) din şcolile urbane sus in într-o pondere mai crescută provocările elevilor ca factor determinant pentru agresivitatea profesorilor. Mai mult, în cazul consilierilor şcolari, provocările din partea elevilor constituie singurul factor care înregistrează varia ie a opiniilor exprimate, în func ie de mediul de reziden ă. Acest aspect poate fi o consecin ă a influen ei conexe a diferi ilor al i factori care ac ionează asupra elevilor din mediul urban şi care pot influen a un comportament neadecvat în spa iul şcolii. Pe de altă parte, în mediul urban sunt situate mai multe şcoli de nivel postgimnazial în care provocările elevilor (tot ca o consecin ă a contextelor sociale în care sunt plasa i) sunt mai frecvente şi mai dificil de gestionat. Aceste provocări sunt principală sursă a violen ei profesorilor fa ă de elevi, o violen ă pe care personalul didactic al şcolii o atribuie, oarecum, exteriorului şcolii: este provocată de elevi (datorită diferi ilor factori de influen ă anterior men iona i), iar răspunsul violent al profesorilor, fără a fi acceptat, este explicat/justificat ca o consecin ă a violen ei elevilor îndreptată spre şcoală.

Graficul nr. 7. Dificultă i de comunicare ca determinan $i$ ai violen ei profesorilor fa ă de elevi

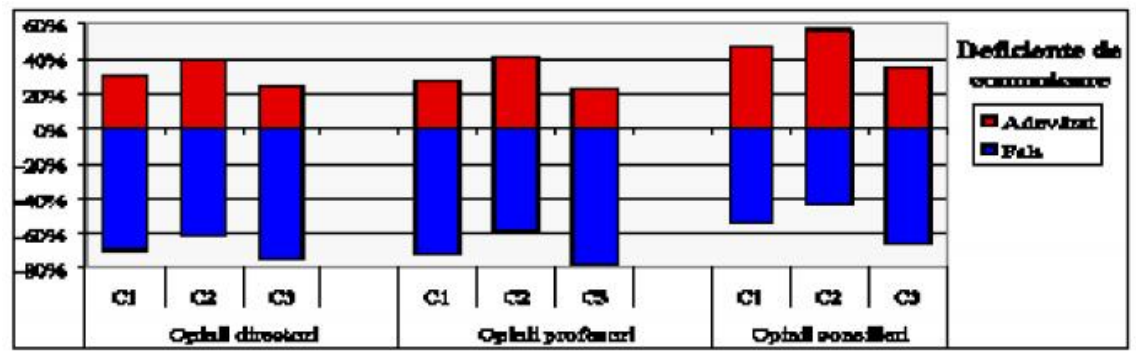

Deficien e de comunicare cu elevii sau părin ii (C):

$\mathrm{C} 1$ : deficien e de comunicare cu elevii

C2: provocări din partea elevilor

C3: deficien e de comunicare cu părin ii, cu efecte asupra rela iei cu elevii 
Cea de-a doua perspectivă explicativă a violen ei profesorilor fa ă de elevi face referire la factorii de mediu educativ, unde consilierii şcolari se detaşează oarecum de opiniile împărtăşite de directori şi profesori. Pentru directori şi profesori, lipsa abilită ilor profesorilor de a coordona clasa constituie principala cauză a violen ei profesorilor fa ă de elevi (34,8\%, respectiv $22 \%$ ). În acest sens, programele de formare care vizează managementul clasei de elevi se dovedesc a fi, încă, o necesitate pentru resursa umană din şcoală. Pentru consilierii şcolari motiva ia scăzută a profesorilor şi presiunea exterioară în organizarea activită ii proprii de predare sunt văzute ca principalele surse de tensiune care duc la violen a profesorilor fa ă de elevi (fiecare factor având o pondere de $43,1 \%$ dintre răspunsurile exprimate de consilieri). Lipsa abilită ilor profesorilor de a coordona clasa de elevi este recunoscută ca determinant al violen ei profesorilor, dar într-o pondere mai pu in semnificativă (aproape o treime dintre consilieri împărtăşesc această opinie). Dacă directorii şi profesorii plasează principala cauză a violen ei profesorilor fa ă de elevi la nivelul profesorului prin identificarea unor abilită i absolut necesare oricărui profesor, consilierii şcolari vad cauzele violen ei profesorilor fa ă de elevi

Graficul nr. 8. Factori de mediu educativ determinan i ai violen ei profesorilor fa ă de elevi

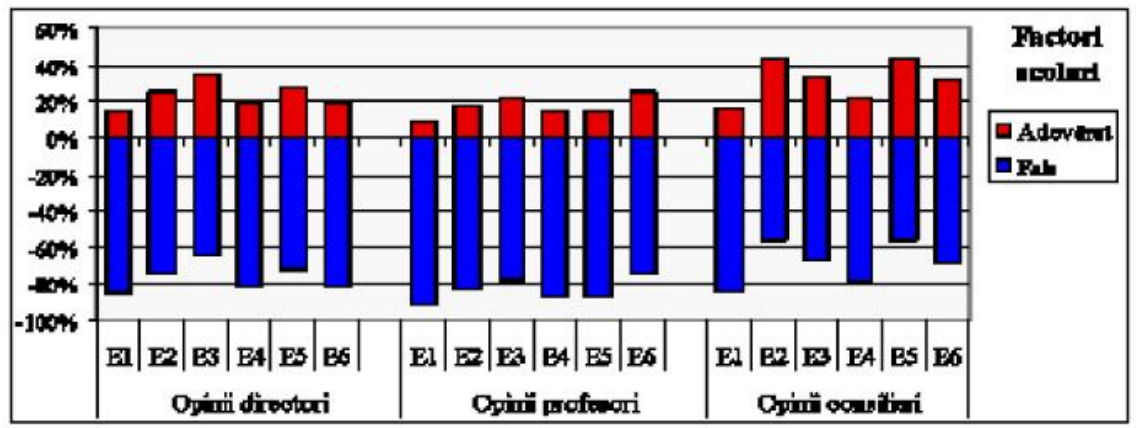

Factori de mediu educa ional (E):

E1: impunerea for ată a autorită ii profesorilor/atitudini autoritariste în rela ia cu elevii

E2: nivel scăzut de motiva ie a profesorilor (salarizare, recunoaştere socială etc.)

E3: lipsa abilită ii profesorilor de a coordona/gestiona clasa

E4: lipsa cunoștin elor de psihologia vârstelor

E5: presiunea exterioară în organizarea activită ii proprii de predare

E6: impunerea de sarcini multiple, în afara normei didactice 
inoculate din exterior profesorilor (lipsa salariilor motivante, lipsa recunoaşterii sociale, presiune exterioară cu privire la organizarea activită ilor de predare).

Oricare ar fi cauzele violen ei profesorilor fa ă de elevi, ele pot fi prevenite şi combătute prin elaborarea unor strategii eficiente de prevenire şi combatere a violen ei şcolare, bazate pe comunicare, cooperare, dorin ă de a lucra împreună pentru dezvoltare reciprocă.

\section{Concluzii şi perspective deschise asupra politicilor educa ionale}

Violen a şcolară este rezultatul unui complex de factori familiali, sociali, şcolari, de context.

Actorii şcolari investiga i au eviden iat variate cauze ale violen ei între elevi (factori individuali, socio-familiali, şcolari). Elevii identifică mai curând la nivelul şcolii cauzele violen ei (climatul concuren ial), în timp ce pentru profesori familia este principala responsabilă pentru actele de violen ă ale elevilor.

Datele arată că principalii factori care determină violen a elevilor fa ă de profesori sunt cei individuali şi cei socio-familiali (opinie sus inută, în special, de cadrele didactice). Pentru elevi primează factorii şcolari. Din perspectiva consilierilor şcolari instabilitatea emo ională, rela iile conflictuale din familie, grupurile de apartenen ă din afara şcolii şi din cadrul şcolii sunt principalii determinan i ai fiecărei categorii de factori de influen ă ai violen ei elevilor fa ă de profesori.

Cauzele violen ei profesorilor fa ă de elevi au fost identificate la nivelul dificultă ilor de comunicare (determinate mai curând de provocările venite din partea elevilor) şi de factorii de mediu educa ional (condi ii materiale, climat organiza ional, recunoaştere socială).

Existen a unor perspective diferite asupra cauzelor violen ei şcolare la nivelul grupurilor de actori ai şcolii, relevă necesitatea derulării unor ac iuni comune de cunoaştere şi recunoaştere a tuturor formelor de violen ă posibil a fi 
manifestate în spa iul şcolii, a determinan ilor şi a implica iilor. Dincolo de simpla afirma ie cu privire la punerea laolaltă a actorilor şcolii în vederea interac iunii şi dezvoltării de ac iuni comune de prevenire şi combatere a violen ei şcolare, este nevoie de dezvoltarea unor programe, politici, strategii de interven ie care să-i pregătească pe actorii şcolii să ac ioneze conştient, informat, coerent în vederea prevenirii şi combaterii violen ei şcolare. Au existat, cel pu in în istoria recentă a şcolii, diferite demersuri de informare, sensibilizare a actorilor, consiliere pentru agresori şi victime, inclusiv consiliere între semeni (peer-mediation), demersuri focalizate pe prevenirea şi combaterea violen ei. Şi, totuşi, constată că profesorii şi elevii au opinii oponente cu privire la cauzele violen ei. Cum pot aceşti actori să lucreze împreună împotriva violen ei şcolare, dacă opiniile lor sunt divergente cu privire la determinan ii fenomenului? Poate tocmai ac iunile în care îi încurajăm să se implice ar trebui schimbate, poate gestionarea la nivel centralizat a fenomenului ar necesita revizuiri, poate redefinirea fenomenului în ansamblu. Nu ne propunem, aici, decât să propunem, pe baza constatărilor din ancheta derulata şi a analizei rezultate, a unor posibile căi de ac iune care pot lua forme variate, de la simple strategii definite la nivelul şcolilor, până la măsuri de politică educa ională, implementate la nivel de sistem.

Posibile modele remediale pentru prevenirea şi combaterea violen ei şcolare:

o Dezvoltarea unui sistem de formare a cadrelor didactice în care fiecare cadru didactic să aibă posibilitatea de a-şi dezvolta competen e specifice de cunoaştere, recunoaştere, combatere, prevenire a actelor violente. Competen ele astfel dezvoltate vor avea în vedere atât grupul de elevi cu care lucrează, părin ii acestora, colegii de şcoală, dar şi propria persoană. Dezvoltarea unor competen e reale şi eficiente la nivelul profesorilor vor orienta ac iunile acestora spre buna gestionare a clasei de elevi, buna gestionare a rela ionării cu elevii, bună planificare, logică şi coerentă a tuturor demersurilor întreprinse în vederea prevenirii şi combaterii violen ei şcolare. Acest sistem / modul de formare profesională continuă ar fi util să func ioneze ca o continuare firească a unui proces de dezvoltare a competen elor început în formarea ini ială ca profesor. De aici relevă, încă o dată, necesitatea dezvoltării unor module tematice adaptate nevoilor prezente ale sistemului de educa ie, şi care să orienteze formarea ini ială a profesorilor (în cadrul modulelor psiho-pedagogice urmate în universită i).

o Dezvoltarea unor sisteme de consiliere a părin ilor, în cadrul unor 
servicii sociale de proximitate. Aceste servicii ar putea fi adresate, cu prioritate, părin ilor elevilor care manifestă diferite forme de violen ă în spa iul şcolar. Reglementările cu privire la astfel de servicii nu constituie o provocare din perspectiva ini ierii şi emiterii unor norme, metodologii de func ionare, ci din perspectiva implicării părin ilor în serviciile de consiliere.

o Dezvoltarea unor sisteme eficiente de monitorizare a elevilor care manifestă comportamente violente. Chiar dacă aceste sisteme de monitorizare ar implica sporirea numărului de consilieri şcolari (provocare de la nivelul sistemului, asupra căreia nu insistăm aici), este necesar să accentuăm aici necesitatea urmăririi într-o perioadă considerabilă de timp a elevilor care manifestă comportamente violente, concomitent cu implicarea elevului în programe de consiliere şi în ac iuni în care să fie responsabilizat şi valorificat în acord cu interesele, abilită ile fiecăruia.

o Reluarea şi sus inerea ini iativei de monitorizare a actelor de violen ă şcolară, astfel încât, la nivelul sistemului să existe o imagine clară asupra inciden ei fenomenului. Sistemul de indicatori există, metodologia de utilizate există, acestea fiind dezvoltate de Ministerul Educa iei Na ional, în cadrul unui proiect structural. Este necesară doar identificarea mecanismelor de stimulare, motivare a şcolilor să declare actele de violen ă şi să le înregistreze. Datele ob inute ar fi utile pentru fundamentarea unor ac iuni la nivelul sistemului de educa ie şi care să contribuie la prevenirea şi, dacă situa ia o cere, la contracararea actelor de violen ă şcolară.

o Realizarea unor parteneriate între Ministerul Educa iei Na ionale şi Ministerul Tineretului şi Sportului în vederea facilitării participării în tabere tematice focalizate pe prevenirea şi combaterea violen ei, a elevilor care au avut diferite devieri comportamentale. Pentru aceasta este necesară definirea ca prioritară a tematicii privind prevenirea şi combaterea violen ei, dar şi reglementări clare referitoare la activită ile încurajate a se derula cu tinerii şi care ar trebui focalizate pe cunoaştere de sine şi dezvoltare personală.

\section{Note}

1. Graficele prezentate în acest articol apar in autoarei. 


\section{Referin e}

- GHID pentru structurile cu responsabilită $i$ in prevenirea și combaterea violen ei în mediul şcolar de la nivelul unită ii şcolare, de la nivel jude ean şi de la nivel na ional. (2011). ISE, MECTS.

- Apostu, O., Fartuşnic, C., Horga, I., Jigău, M., Novak, C., Scoda, A., \& Voinea, L. (2016). VIOLEN A ÎN ŞCOALĂ. Studiu pilot privind metodologia de analiză a fenomenului violen ei în şcoală, Bucureşti, Institutul de Ştiin e ale Educa iei.

- Bègue, L. (2004). La violence scolaire et ses déterminants. In M.-C.

Toczek, \& D. Martinot (Eds.), Le défi éducatif, Paris, Colin, 307-332.

- Debarbieux, É. (1996). La violence en milieu scolaire. 1- État des lieux, Paris, Esf.

- Debarbieux, É. (2006). Violence à l'école: un défi mondial?, Paris, Armand Colin.

- François, D. (2002). Le déclin de l'Institution, Paris, Seuil.

- Jigău, M. (coord.). (2008). Timpul elevilor, Buzău: Editura Alpha MDN.

- Jigău, M., Liiceanu, A., \& Preoteasa, L. (2006). Violen a în şcoală, Buzău, Alpha MDN.

- Pain, J. (1997). Violences et prévention de la violence à l'école. Les Sciences de l'Education, 30(2), 57-87.

The online version of this article can be found at: http://revped.ise.ro/category/2018-en/

\section{(cc) $\mathrm{BY}-\mathrm{NC}-\mathrm{SA}$}

This work is licensed under the Creative Commons Attribution-NonCommercial-ShareAlike 4.0 International License.

To view a copy of this license, visithttp://creativecommons.org/licenses/by-ncsa/4.0/ or send a letter to Creative Commons, PO Box 1866, Mountain View, CA 94042, USA.
Versiunea online a acestui articol poate fi găsită la:http://revped.ise.ro/category/2018-ro/

\section{(cc) EY-NC-SA}

Această lucrare este licen iată sub Creative Commons Attribution-NonCommercial-ShareAlike 4.0 International License.

Pentru a vedea o copie a acestei licen e, vizita $i$ http://creativecommons.org/licenses/by-nc-sa/4.0/ sau trimite i o scrisoare către Creative Commons, PO Box 1866, Mountain View, CA 94042, SUA. 